\title{
Panorama of teaching in higher education institutions under science, technology, engineering and mathematics (STEM) programs
}

\author{
Panorama de la enseñanza en instituciones de educación superior, en programas de \\ ciencia, tecnología, ingeniería y matemáticas (STEM)
}
Visão Geral do Ensino em Instituições de Ensino Superior, em Programas de Ciência, Tecnologia, Engenharia e Matemática (STEM)

\author{
Maria Amparo Oliveros Ruiz ${ }^{1}$ id
}

Received: August 2020

Accepted: Octuber 2020

How to cite: Oliveros-Ruiz, M. A. (2021). Panorama of teaching in higher education institutions under science, technology, engineering and mathematics (STEM) programs. Revista Científica, 40(1), 2-12.

https://doi.org/10.14483/23448350.16764

\begin{abstract}
Student enrolment in science, technology, engineering, and mathematics (STEM) programs is critical in Mexico. Mexican employers reported having difficulty finding people with the necessary skills to fill vacancies in STEM areas. Our study analysed student responses regarding the main factors in choosing a STEM career. These included everything from gender roles to family opinions. The resulting indicators showed how cultural training, youth identity and gender equity impact career choices related to STEM for students in Mexico's border areas of Baja California and Sonora. Our results can help define strategies universities should implement and success factors for recruiting and retaining students in STEM programs.
\end{abstract} Keywords: STEM, STEM+A, higher education, careers

\section{Resumen}

La inscripción de estudiantes en programas de ciencias, tecnología, ingeniería y matemáticas (STEM) es crítica en México. Empleadores mencionaron tener dificultades encontrando personas con habilidades para llenar vacantes en áreas STEM. Los resultados mostraron que la capacitación cultural, identidad juvenil y equidad de género impactan en las elecciones profesionales por parte de estudiantes, en el área fronteriza de Baja California y Sonora. Esto puede definir qué estrategias diseñar e implementar en las universidades y cuáles son los factores de éxito para reclutar estudiantes en estos programas.

Palabras clave: CTIM, STEM, STEM+A, educación superior, carreras

1. Universidad Autónoma de Baja California. Mexicali, Baja California, México. amparo@uabc.edu.mx 


\section{Resumo}

A matrícula de alunos em programas de ciência, tecnologia, engenharia e matemática (STEM) é crítica no México. Os empregadores mencionaram ter dificuldade em encontrar pessoas com habilidades para preencher as vagas nas áreas STEM. Os resultados mostraram que o treinamento cultural, a identidade jovem e a igualdade de gênero afetam as escolhas profissionais dos estudantes na área fronteiriça de Baja California e Sonora. Isso pode definir quais estratégias desenvolver e implementar nas universidades e quais são os fatores de sucesso para recrutar alunos para esses programas.

Palavras-chaves: STEM, STEM, STEM + A, ensino superior, carreiras

\section{Introduction}

The science, technology, engineering, and mathematics (STEM) model, according to (Kennedy y Odell, 2014), is an attempt to promote critical thinking, analysis, and teamwork by encouraging students to integrate real-world processes and concepts for the development of competencies for their education, work, and life. The STEM fields may seem inaccessible to many students for reasons of finances or resources, but STEM programs endeavour to increase access to these subjects. STEM initiatives have now become one of the key objectives of educational planning not only in countries such as the United States, the United Kingdom, Australia, Japan, or Finland but also in the European Union and international organisations. Even leading companies in different, but technologically linked, sectors have joined forces with governments to develop programs or initiatives to promote technological vocations among young people (Boe et al., 2011).

\section{Necessary STEM Skills in the Future Workforce}

Part of the push for STEM originates in the declining enrolment in some disciplines combined with the projected growth of STEM-focused jobs. The widely quoted report, 'The World Needs
More Scientists' (UNESCO, 2017), called for a substantial rise in the percentage of scientific and technological researchers in the total workforce. Projections from several countries indicate that the demand for STEM-educated labour will grow over the coming years, and there is a widespread concern that the supply of STEM-educated people will be too small to meet future demands (Bjørnstad et al., 2008). According to the Organisation for Economic Co-operation and Development (OECD) report (2015), Mexico has a low level of eligible employees for high-level technological activities; 30,9\% of Mexican employers report having faced difficulties in finding people with competencies needed to fill vacancies in STEM areas, which can be attributed to low levels of innovation in the Mexican economy. In the 2018 Global Innovation Index, Mexico was ranked 56th (Wipo, 2018). Among OECD countries, Mexico has a very low score on patents and relevant scientific publications. In 2017, the Mexican Institute of Industrial Property granted a total of 8510 patents, with only 4,78\% belonging to Mexican holders (Impi, 2018). In terms of scientific publications, Mexican production has stagnated in recent years. From 2012 to 2015, the share of Mexican production compared to the global total was $0,60 \%$. In the five-year period from 2011 through 2015, Mexico ranked $22^{\text {nd }}$ out of 34 member nations in the production of scientific articles (Conacyt, 2015).

There is also a concerning gender gap that nations hope will be addressed with increased STEM education. While boys and girls have similar skills in mathematics and science, their attitude toward learning and aspirations for the future are remarkably different, which has a significant effect on their decision to continue studies of higher education and with their career choice (Archer et al., 2012, pp. 881-908). Previous research (Dabney, 2013) has suggested that men and women generally have similar abilities to study science and technology. The gender gap in career choice seems to arise from attitudinal and social aspects; women 
may be deterred from STEM studies because of the absence of female role models in science and engineering education, the curricular subjects being irrelevant for women, science didactics and class environment being most appropriate for men, male visions of science and the cultural and social pressure of gender roles (Blickenstaff, 2005). To reduce the gender gap, there is a long way to go in promoting a positive attitude towards women learning mathematics and investing in this area (Blickenstaff, 2005). If the number of women choosing a STEM education continues to be low, there will continue to be few role models that young women can emulate, and the cycle will simply be perpetuated (Scott, 2014).

Gender differences in career aspirations and expectations may be one of the factors that lead to a gender-segregated labour market, which, in turn, may have unintended consequences for individuals and societies (Uthoff, 2006). The absence of women in the labour market is associated with less development and economic growth. This paper shows the most relevant results obtained by the application of the Interests \& Recruitment in Science Questionnaire to evaluate the opinions of university students regarding their interest and recruitment in science. These results will permit stakeholders to establish strategies for recruiting and retaining higher education students in science and engineering careers.

\section{The Approaches of Learning in Engineering and the New Educational Model of the Secretary of Public Education}

The level of well-being and competitiveness of nations depends on the quantity and quality of their scientists and engineers. At present, in most developed countries there is a special concern to attract young people to these disciplines and to train them with the highest possible quality. Figure 1 shows the main approaches to improving the attractiveness of engineering subjects and facilitate learning from early stages to undergraduate levels.
The challenges of the $21 \mathrm{st}$ century for the knowledge society imply a change of educational strategies to boost the economic development of the country. The STEM model is the integration of science, technology, engineering, and mathematics, combining classroom learning with real-world experiences (Sanders, 2009) to provide students with the professional and technical skills utilise science and technology to raise quality of life of the population.

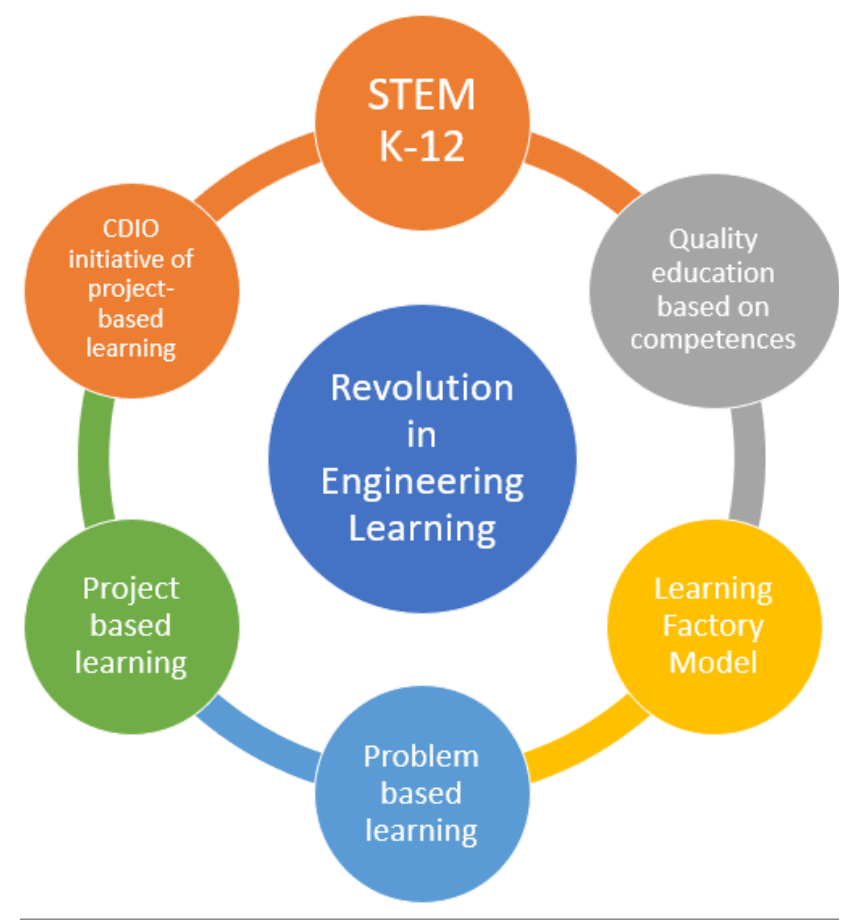

Figure 1. New Approaches to Learning in Engineering.

\section{The STEM Model}

According to Toma (2015), STEM is an interdisciplinary approach whose main objectives are to respond to the economic challenges present in all nations, to identify the needs of workers who require more flexible knowledge and new skills to adjust to current labour and social requirements, and to emphasise the need to address technological and environmental problems through student literacy. 


\section{STEM as a Tool to Encourage Studies in Science and Engineering}

With the aim of promoting the inclusion of women in the technology workforce, as a fundamental element for economic development, the OECD establishes educational policies for Latin America based on the STEM model; this model combines a number of different types of content that emphasise educational strategies to motivate women in engineering, such as: 1) internships for the practical application of the knowledge acquired in school; 2) implementation of workshops; 3) debates, discussion boards and critical thinking; 4) science fairs and contests, clubs and research networks and 5) workshops and talks of successful mentors in the STEM areas (Figure 2).

\section{Methodology}

The applied assessment instrument consists of a total of 22 open and closed questions, and its preparation was based on the IRIS-Q (Interests and Recruitment in Science Questionnaire, 2008), asking about some contextual, interpersonal educational characteristics and personal experiences.

The questionnaires were given to students in the fourth to ninth semester in STEM programs: 12 programs in the School of Engineering at Autonomous University of Baja California (UABC), 4 programs for the Polytechnic University of Baja California (UPBC) and four programs for the State University of Sonora (UES). E-mail addresses were collected through university classroom teachers to assemble a database to apply the survey for this investigation, which was carried out from March to June of 2017. There were a total of 1154 students surveyed from a total population of 6054 engineering students. Participation per institution breakdown was as follows: UABC $43,3 \%$, UPBC $30,5 \%$ and UES $26,2 \%$ (Table 1 ).

It is important to note that these results are a starting point for interpretation and data analysis and depend on the enrolment participant at the time of the survey. Table 1 shows the breakdown of participation of each institution involved in the study sample. From the 6054 total engineering-student population, only 1154 were selected for the survey.

\section{Data Processing}

The questionnaires were applied to the students of the different universities, and the total surveys answered were obtained through the use of a reliable web-quest control platform. The results were reviewed by the head of the research project to authorise the capture of information and processing of the database designed in Excel $^{\circledR}$ format. Later the SPSS ${ }^{\circledast}$ statistical program was used for extracting data, which are presented in tables in the results section. To describe the data, the following criteria were considered: not important, less important, neutral, important and very important.

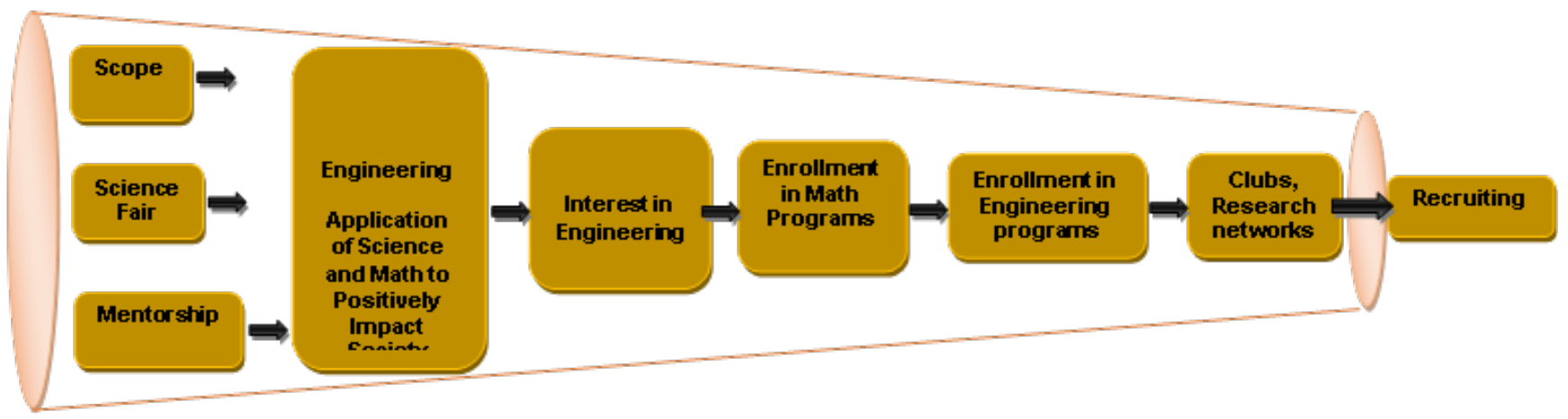

Figure 2. STEM Model of the OECD. Source: (OECD, 2015). 


\section{Results}

A total of 1154 surveys were collected; the 947 male survey responses represented $82,1 \%$ of the total, while the remaining 207 surveys were from female students, as shown in (Figure 3 ).

\section{School Experience for Career Choice}

The most important factor in career choice was interest in scientific subjects; $50,2 \%$ of female subjects and $45,0 \%$ of male subjects considered it important. The least important aspect was experience, as selected by $29,5 \%$ of female subjects; $29 \%$ of male subjects selected experiments and lab work.

Evidently, laboratory practice is essential to STEM models. To do this, it is necessary to propose practice from an early age, not only for students but also for teachers who have not had the opportunity to develop this type of skill (Bosh, 2011).

\section{Importance of People in Career Choices}

It is important to recognise the influence exerted by interpersonal relationships, whether family, teachers, or others, in students' career decisions. Parents dominate regarding influence: $37,7 \%$ of women mentioned the importance of mothers or stepmothers, and $30,2 \%$ of men said the same thing. Among other important influences in career selection is the father or stepfather, with $32,4 \%$ of women thinking it is very important and $31,2 \%$ of men. Least important are vocational counsellors and teachers at school.

In the questionnaires, the women expressed the importance of support from their parents in following this type of career path. Therefore, it was observed that families are changing their idea of a traditional role for women, whom they strongly advise and support (Razo, 2008).

It is important to mention that, aiming to strengthen the image of parents, the new educational model of the Secretary of Public Education emphasises the promotion of educational training programs on early childhood development, for parents to participate more actively in their children's development.

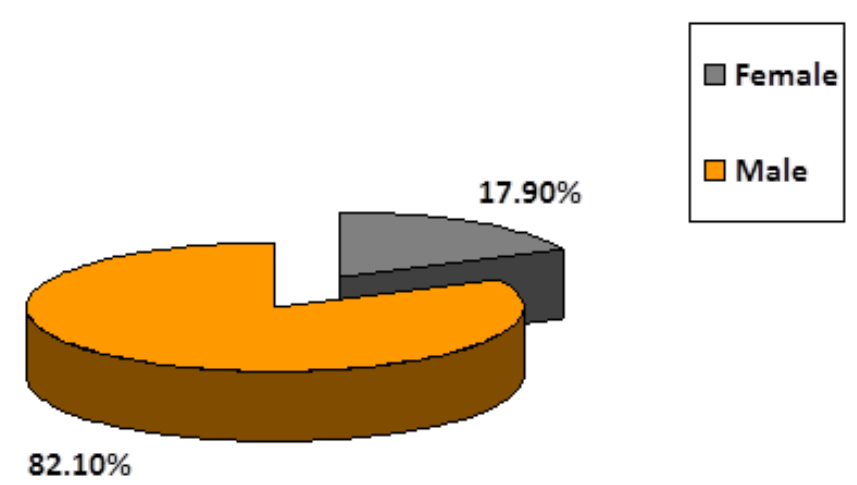

Figure 3. Students by gender.

Source: author's development.

Table 1. Study Population

\begin{tabular}{ccccc}
\hline Institution & $\begin{array}{c}\text { Total enrolment at the } \\
\text { time of the study }\end{array}$ & $\begin{array}{c}\text { Enrolment in } \\
\text { engineering programs }\end{array}$ & $\begin{array}{c}\text { Students participating in the } \\
\text { STEM survey programs }\end{array}$ & $\begin{array}{c}\text { Percentage of } \\
\text { participation (\%) }\end{array}$ \\
UABC & 65323 & 4314 & 500 & 43,3 \\
UPBC & 1472 & 1342 & 352 & 30,5 \\
UES & 2021 & 408 & 302 & 26,2 \\
TOTAL & 68816 & 6064 & 1,154 & 100 \\
\hline
\end{tabular}

Source: author's development. 
Table 2. Perception about the importance that some people had for the election of the career.

\begin{tabular}{lccccc}
\hline \multicolumn{1}{c}{ People } & \multicolumn{3}{c}{ Scale of values (percentages) } \\
& Not important & Less important & Neutral & Important & Very important \\
Mother or stepmother & 16,0 & 10,9 & 19,1 & 16,1 & 37,9 \\
Father or stepfather & 22,3 & 11,2 & 17,6 & 15,5 & 33,4 \\
Good teachers & 12,2 & 9,4 & 22,9 & 29,3 & 26,2 \\
Friends (including boyfriend) & 23,8 & 14,4 & 23,0 & 18,8 & 19,0 \\
Brothers and other relatives & 24,1 & 14,6 & 21,7 & 17,2 & 22,3 \\
Vocational counsellors at & 27,9 & 16,3 & 23,4 & 17,9 & 14,4 \\
school & & & & \\
\hline
\end{tabular}

Source: author's development.

\section{Extracurricular Activities and Career Choices}

Another important topic for the investigation is the relevance of certain activities that influence a student to be inclined to a certain university program. In the case of books and magazines dealing with popular science, $35,7 \%$ of women considered them important, as well as $30,2 \%$ of men. Science fiction books or films can also help students cultivate their interest in science; $25,7 \%$ of women and $29 \%$ of men say this was a significant influence. This category includes learning experiences that took place outside the school day and were not dependent on the formal system, even if these activities took place on school premises or school-initiated programs for the reinforcement of STEM skills (for example, in larger vulnerable groups).

\section{Opinion about Gender Overrepresentation in the Program of Choice}

Students were asked whether they felt their gender was overrepresented in their program of choice. In summary, $61,6 \%$ of men and women did not think that their gender was overrepresented. In the open questions, men expressed that women are as capable as men in science, while women felt that more programs with female role models are needed to inspire more female STEM students.

In the report of the First National Meeting of Young People in Engineering, in November 2015 (Engineering Academy Mexico, 2015) regarding the presence of women in engineering, it was pointed out that there is still gender discrimination based on taboos such as the intellectual incapacity of women in face of the greater male presence and that this limits the opportunities in the labour market.

\section{Opinion on Aspects of Learning and Career Motivation}

The opinions of the students regarding various aspects of learning and career motivation were collected from the following six aspects included in the questionnaire:

1. I will do better than the average grade in my program.

2. I easily learn the topics of this program.

3. I'm sure I'm pretty good at this program's subject.

4. I am very motivated to study this program.

5. I'll probably quit the program before I'm done.

6. I won't quit the program before I'm done. 
7. Students' perceptions of learning and motivation were generally positive. The most important aspect was 'I won't quit the program before I'm done', followed by 'I easily learn the topics of the program', which is very relevant since these students were in the terminal stage of the program.

\section{Opinion on the Importance of the Future Factor}

Students were particularly concerned about the future. They rated highly the concerns of grow as a person, do something of interest, use their talents and skills and work on something important for society. They also mentioned making money soon but ranked that slightly lower. Most students expressed being aware of the growing need for engineers trained in creative skills to generate innovation and patents and the ability to interpret data and soft skills such as leadership, professional ethics, a command of English and teamwork.

\section{Science, Technology, Society + Innovation Model as a Proposal for Implementation}

The complexity of the new requirements for engineers of the 21 st century should give way to a new form of teaching as well as the creation of a system formed by industry, government, the different educational systems and society. Therefore, a model that provides an adequate functionality in the productive sector was proposed. This model is based on the Science, Technology, Society + Innovation $(\mathrm{STS}+\mathrm{I})$ model and encompasses science, technology and society in an innovative system. The STS+I model establishes that STEM skills are required to fulfil the professional profiles of technical personnel. In this sense, STS+I and STEM models are complementary.

The proposed model aligns the current and future challenges of the industry with educational programs and schemes for training and talent development as well as the programs of the federal government through the new educational model. As a field test and with the objective of validating the model, it was implemented in one of the most dynamic, technological, competitive, and fastest growing companies in the state of Baja California, Mexico. This allows us to observe the path of involvement of the actors in training under a STEM scheme from basic to professional levels. We could also observe the way in which educational systems can be incorporated into the model, including the advantages that the new Mexican model of education can bring from a global focus point in which corporate citizens participate.

As shown in Figure 4, the model includes four systems: strategic networking, economic and social development, competitiveness and management and business intelligence. The strategic networking system aims to align technical and engineering competencies with current and future challenges, continually updating study programs through the execution of a technological route map where academics integrate new competencies that will train students in the latest technologies and let them experiment and apply their learnings through laboratories shared between companies and educational institutions, thus ensuring the infrastructure and educational programs required for talent training. On the other hand, the academic body is responsible for creating the academic modules, updating their lines of research to the requirements of the environment, promoting applied research, and generating knowledge economy through project incubation, products and services that benefit companies and society.

The system, called Competitiveness and Management, aims to boost STS+l in industry through management systems, increasing the indicators of competitiveness of companies. However, besides innovation bringing great benefits for the company, a fundamental part is the integration of society to the industry, because not only are technical or engineering competences required to perform industry functions but also soft topics or skills such as teamwork, conflict management, emotional 


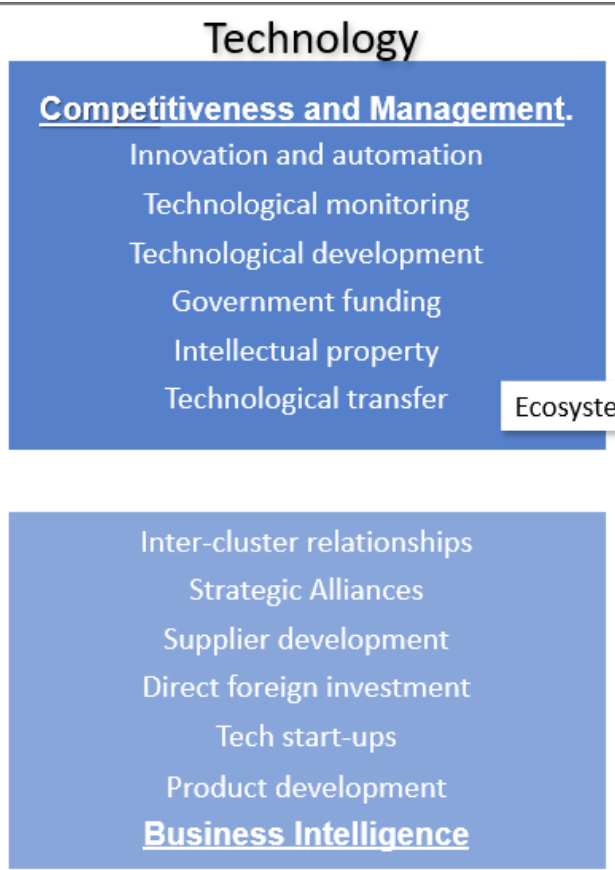

Innovation

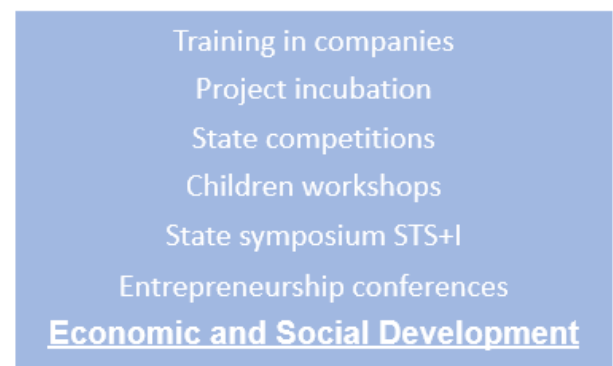

Society

Figure 4. STS+I.

Source: author's development.

intelligence, leadership and change management; these will allow the new partner of the company to make faster, more accurate and objective decisions with better results.

Currently, a STEM internship is in operation for high school and undergraduate students who are $100 \%$ integrated into the company and therefore able to acquire these management skills in addition to learning their usual curriculum. In addition, these students will have greater insight into the industry by knowing the departments that comprise it and its impacts and responsibilities. They also will have an integral training with management modules and additional certifications of project management, problem solving, data analysis and English. Companies that adopt this program will have the benefit of pre-selection of talent and the optimisation of the learning curve because the student will be training within a dual scheme.

The system, called Business Intelligence, aims to interrelate companies, educational institutions, chambers of commerce, government institutions, investors and society. It identifies common challenges and problems through clusters and networks in the industrial area, where they develop multidisciplinary teams to find and solve problems; through the methodology or flow of innovation defined in each program, the products are developed, generating new technology-based companies. Suppliers with new products or services are developed, and high value products are generated, creating their own technology and intellectual property protection and improving competitiveness of companies for the generation of national supply and creation of jobs of high value for the country.

Lastly, the system called Economic and Social Development aims to promote innovation and creativity at all levels of society to create projects that improve quality of life. It has been proved that people educated and formed in a STEM+A model produce the greatest impact on innovation and entrepreneurship, supported by patents generation 
and the founding of new companies (LaMore et al., 2013). Therefore, it is important that the actors of the different programs have an interdisciplinary approach, where the different disciplines, such as teaching, architecture, engineering and art school, allow creativity and innovation to permeate at all levels, from the integration of science, technology, engineering, mathematics and arts in children through workshops, games and challenges that will awaken creativity and innovation contests with challenges defined according to the strategic areas of the states that meet or generate a certain need. Likewise, the workshops of innovation or management of technology for companies have been very useful so that they can be implemented within these companies and create systems that improve their indicators, and on the other hand, with this system we are contributing with the $\mathrm{Na}$ tional Development Plan that seeks to boost SME's and innovation in our country.

\section{Discussion}

This study shares a panorama of teaching in higher education institutions under STEM programs of three public universities. The main results highlight how cultural training, youth identity and gender equity impact STEM career choices by students in the border area of Baja California and Sonora. This can define the success factors for recruiting and retaining students in these programs and which strategies universities should implement to achieve this recruitment and retention.

According to Schreiner and Sjøberg, (2004), the Relevance of Science Education project was born due to the worrying decrease in the interest of young people for STEM studies in Europe in recent years. This translates into a decrease in the number of technicians and scientists needed to maintain the key development of the national science and technology systems supported by the Rocard report and other studies (PISA, Relevance of Science Education). In the same sense, in Latin America, $18 \%$ of the students graduate annually in STEM programs (RICYT, 2014). The results of this work are similar to other studies conducted in more developed economies. The problems of inequality, desertion and low interest for STEM careers persist equally in both developed and emerging economies.

\section{Conclusions}

In summary, this document presents the results of the analysis of factors influencing students currently pursuing a university STEM education. It is observed that the gender gap is still a challenge for STEM education in Mexico; of the 1,154 students surveyed, $82,1 \%$ are male while $17,9 \%$ are female.

The most important aspect influencing program choice is its students' interest in scientific subjects and their experience with experiments and laboratory work. According to Bosh (2011), laboratories offer students unprecedented power to explore, measure and learn about the world of science. That is what is needed to solve the problems presented by society: to train students who can learn about the world of science.

For both men and women, the people most influential in a student's career choice are family members; vocational counsellors and teachers in school were considered the least important. It is vital to raise awareness for institutions to develop a STEM-program that strengthens the skills of engineers in the 21st century. The report of the Engineering Academy of Mexico refers to the formative efficiency of engineers; poorly trained engineers leads to costly remediation activities or training delays, as well as desertion and frustration of young people. Mexico cannot aspire to a higher level of development if the complete training chain from basic to postgraduate education does not meet quality and quantity requirements that the country requires. The universities must promote STEM programs levels to arouse the interest of the students in science and engineering careers. To this end, the new educational model of the Secretary of Public Education emphasises the promotion of 
training programs in early childhood development and updated didactic material for teachers of all educational levels.

With regard to extracurricular activities that motivate students to inquire about the relevance of science, there are scientific books and magazines, science fairs and clubs and scientific photography. Regarding gender overrepresentation, they accepted that it exists. However, men expressed that women have the same ability as men in science while considering the need to provide better representation of successful women to motivate them in STEM areas.

In addition, students' opinions on learning and career motivation were considered. Students' perceptions of learning and motivation are positive. The most important was not to quit the program before finishing, followed by easily learn the subjects of the program, which is very relevant since the students are in the terminal stage of their studies. The factors valued with the highest percentages were opinions about the importance of the future, indicating an optimistic profile and related to growth as a person, doing something of interest and using talents and skills, as well as working on something important for society. The concept of earning money quickly earned a slightly lower score. Also, students were very positive towards soft skills such as leadership, professional ethics and English language. In general, future engineers assign a high value of utility to STEM careers.

The implementation of an educational system based on STEM is a difficult process that requires the intervention of actors from all sectors of government, education, production, and society. Scientific and technological education must, like all other branches of knowledge, be complemented by social responsibility and the enrichment of the student's cultural background. The design of operational models for the improvement of production involving the skills acquired in a STEM educational model is feasible and necessary for the future success in the generation of wealth and well-being of our country. The STS+I model, tailored to the specific conditions of our country, and implemented in a high technology industry, has been validated and successful and can be replicated and improved in other organisations throughout our country.

\section{Acknowledgments}

I would like to thank Conacyt, Autonomous University of Baja California, State University of Sonora and Polytechnic university of Baja California, for all the support in the development of the present work.

This work was financially supports by Conacyt under he Grant Number 280473

\section{References}

Archer, L., DeWitt, J., Osborne, J., Dillon, J., Willis, B., Wong, B. (2012). Science aspirations, capital, and family habitus: How families shape children's engagement and identification with science. American Educational Research Journal, 49(5), 881-908. https://doi. org/10.3102/0002831211433290

Blickenstaff, J. (2005). Women and science careers: leaky pipeline or gender filter? Gender and Education, 17(4), 369-386. https://doi. org/10.1080/09540250500145072

Boe, M., Henriksen, E., Lyons, T., Schreiner, C. (2011). Participation in science and technology: Young people's achievement-related choices in late-modern societies. Studies in Science Education, 47(1), 37-72. https://doi.org/10.108 $\underline{0 / 03057267.2011 .549621}$

Consejo Nacional de Ciencia y Tecnología (Conacyt) (2015). Informe General del Estado de la Ciencia, la Tecnología y la Innovación. http://www.siicyt.gob.mx/index.php/transparencia/informes-conacyt/informe-general-delestado-de-la-ciencia-tecnologia-e-innovacion/ informe-general-2015/3814-informe-general-2015/file 
Dabney, K., Chakraverty D., Tai, R. (2013). The Association of Family Influence and Initial Interest in Science, 97, 395-409. https://doi. org/10.1002/sce.21060

Instituto Mexicano de la Propiedad Industrial (Impi) (2018). Impi en cifras 2018. https://www.gob.mx/impi/documentos/instituto-mexicano-de-la-propiedad-industrial-en-cifras-impi-en-cifras

IRIS (Interests \& Recruitment in Science) Project (2008). Factors Influencing recruitment, retention and gender equity in science, technology and mathematics higher education. http://iris.fp-7.org/

Kennedy T.J, y Odell M. R.L (2014). Engaging Students In STEM Education. Science Education International. Vol. 25, Issue 3, 2014, 246-258. http://www.icaseonline.net/sei/ september2014/p1.pdf

LaMore, R., Root-Bernstein, R., Root-Bernstein, M. (2013). Arts and crafts: critical to economic innovation. Economic Development Quarterly, 27(3), 221-229. https://doi.org/10.1177/0891242413486186

OECD (2015). The ABC of Gender Equality in Education. The Association of Family Influence and Initial Interest in Science, 97, 395-409. https://doi.org/10.1787/9789264229945-en

Organización de las Naciones Unidas para la Educación, la Ciencia y la Cultura (Unesco). (2017). "The world needs science and science needs women" says UN on new International Day. https://news.un.org/en/story/2016/02/522012world-needs-science-and-science-needswomen-says-un-new-international-day \#. VtBGtitCg7E

Razo, M. (2008). La inserción de las mujeres en las carreas de ingeniera y tecnología. Perfiles Educativos, 30(121), 63-96.

Red de Indicadores de Ciencia y Tecnología (RICyT). (2014). Graduados en educación superior. http://www.ricyt.org/

Sanders, M. (2009). STEM, STEM education, STEMmania. Technology Teacher, 68(4), 20-26.

Scott, J. (2014). Redistributive Impact and Efficiency of Mexico's Fiscal System. Public Finance Review, 42(3), 368-390. https://doi. org/10.1177/1091142113497394

Secretaría de Educación Pública (2017). Nuevo modelo educativo. https://www.gob.mx/sep/documentos/ nuevo-modelo-educativo-99339

Toma, R. (2015). Fundamento, desempeño e inconvenientes de la indagación escolar en ciencias: diseño, implementación y evaluación de una propuesta innovadora (End of Grade Work). University of Burgos.

Uthoff, A. (2006). Brechas del Estado de bienestar y reformas a los sistemas de pensiones en América Latina. Revista de la CEPAL, 89, 9-37. World Intellectual Property Organization (Wipo). (2018). Global Innovation Index 2018. https://www.wipo.int/edocs/pubdocs/en/ wipo pub gii 2018.pdf

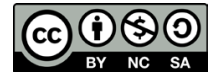

